\title{
THE SIGNIFICANCE OF PROGNOSTIC PROFILING IN THE TREATMENT OF PATIENTS WITH MULTIPLE MYELOMA
}

\section{ZNAČAJ ODREĐIVANJA PROGNOSTIČKOG PROFILA U LEČENJU BOLESNIKA SA MULTIPLIM MIJELOMOM}

\author{
Marko Mitrović1,2, Aleksandra Sretenović ${ }^{1,2}$, Jelena Bila ${ }^{1,2}$
}

${ }^{1}$ University of Belgrade, Faculty of Medicine, Belgrade, Serbia

${ }^{2}$ University Clinical Centre of Serbia, Clinic for Hematology, Belgrade, Serbia

Correspondence: markomitrovic40@gmail.com

\begin{abstract}
Multiple myeloma (MM) is a hematological neoplasia characterized by clonal expansion of the most mature B lymphocytes, plasma cells (Plc), in the bone marrow (BM). Due to new treatment modalities, the 5-years survival has improved in the last 15 years, and nowdays ranges from $60-70 \%$. The individual prognostic profile is based on the biological characteristics of the disease, clinical characteristics of patients and therapeutics response characteristics. The biological characteristics of the disease are defined by the clinical stage according to the Durie-Salmon classification and prognostic indices such the international staging system (ISS) and revised ISS (R-ISS). Numerous different mutations of prognostic significance have been discovered applying methods of molecular genetics such as next generation sequencing (NGS). The age and comorbity status of patients are the most important clinical characteristics because they are crucial for therapeutic choice and suitability for treatment with high-dose chemotherapy and autologous stem cell transplantation. The prognostic influence of therapeutic response is very important and the most powerful prognostic factors are achievements of complete remission (CR) and minimal residual disease (MRD) negativity.
\end{abstract}

Keywords:

multiple myeloma,

prognostic profile
Mitrović M. et al. MedPodml 2020, 71(4):17-24

(c)

The authors declare no conflicts of interest. doi:10.5937/mp71-28137

Editorial board: podmladak.med.bg@gmail.com e-ISSN: 2466-5525 
Multipli mijelom (MM) predstavlja hematološku neoplaziju koja se karakteriše klonskom ekspanzijom najzrelijih B-limfocita, odnosno plazmocita (Plc), u kostnoj srži (KS). Zahvaljujući novim modalitetima lečenja petogodišnje preživljavanje obolelih od MM u značajnoj meri je poboljšano u poslednjih 15-tak godina, tako da danas iznosi 60-70\%. Od presudne je važnosti za svakog obolelog odrediti individualni prognostički profil koji se bazira na: Biološkim karakteristikama bolesti; Kliničkim karakteristikama bolesnika; i Karakteristikama terapijskog odgovora. Biološke karakteristike bolesti su definisane kliničkim stadijumom prema Durie-Salmon klasifikaciji, i prognostičkim indeksima, internacionalnim "staging system" skorom (ISS) i revidiranim ISS (R-ISS) skorom. Metodama molekularne genetike kao što je sledeća generacija sekvencioniranja (NGS) otkrivene su brojne genske mutacije od prognostičkog značaja. Od kliničkih karakteristika bolesnika, ističu se godine života i komorbiditetni status obolelog jer su od ključne važnosti za terapijski izbor i podobnost za lečenje visokodoznom hemioterapijom sa au-

Ključne reči:

multipli mijelom, prognostički profil tologom potporom matične ćelije. Na prognozu bolesti veliki uticaj ima i karakteristika terapijskog odgovora, tj postizanje kompletne remisije (CR) nakon inicijalnog lečenja i negativnost minimalne rezidualne bolesti (MRD).
Uvod

Multipli mijelom (MM) predstavlja hematološku neoplaziju koja se karakteriše klonskom ekspanzijom najzrelijih B-limfocita, odnosno plazmocita (Plc), u kostnoj srži (KS) (1). Prosečna incidencija ove bolesti je 6-7 novoobolelih na 100.000 stanovnika godišnje (2-4). Zahvaljujući novim modalitetima lečenja petogodišnje preživljavanje obolelih od MM u značajnoj meri je poboljšano u poslednjih 15-tak godina, tako da danas iznosi $60-70 \%$ uz mogućnost izlečenja kod 15\% obolelih $(2,5)$. Prognostički faktori od uticaja na tok bolesti i krajnji ishod zasnovani su na:

A. Biološkim karakteristikama bolesti

B. Kliničkim karakteristikama bolesnika

C. Karakteristikama terapijskog odgovora

Prognostički profil bolesnika formira se objedinjavanjem navedenih parametara, što je od značaja za adekvatan individualizovani terapijski pristup.

\section{Biološke karakteristike bolesti}

Imunološki profil bolesti

U odnosu na tip monoklonskog $(\mathrm{M})$ proteina, najčešći tipovi multiplog mijeloma su IgG, IgA i Bence-Jones (BJ) ili MM lakih lanaca, dok se IgD, IgM I IgE MM javljaju znatno ređe. IgA MM se karakteriše agresivnijim tokom bolesti u odnosu na IgG, što korelira sa većom učestalošću $\mathrm{t}(4 ; 14)$ u sklopu IgA MM (6). IgD mijelom često je udružen sa bubrežnom slabošću, uznapredovalom bolešću na dijagnozi, visokim ISS skorom, povišenom koncentracijom LDH i nalazom ekstramedularne bolesti $(7,8)$. Oligoi nesekretorni MM, kao i BJ MM, karakterišu se slabo diferentovanim malignim klonom plazmocita, češćim ekstramedularnim lokalizacijama i agresivnim tokom bolesti (9).
Merenje intaktnih imunoglobulina, kao i određivanje koncentracija $\kappa$ i $\lambda$ slobodnih lakih lanaca, ima klinički i prognostički značaj kako na dijagnozi, tako i tokom praćenja terapijskog odgovora. MM koji se karakteriše sekrecijom kompletnog molekula imunoglobulina lako se dokazuje i prati pomoću standardne elektroforeze (EF) proteina sa imunofiksacijom (IF). Senzitivnost EF proteina je nedovoljna u slučaju sumnje na oligo- ili nesekretorni MM. Uvođenjem testa kvantitativnog određivanja koncentracije lakih lanaca u serumu ("serum-free light-chain", sFLC), ovaj problem je prevaziđen. Kada su u pitanju monoklonska gamapatija neodređene značajnosti (monoclonal gammpathy of undetermined significance, MGUS) i "smouldering" MM (SMM), brojnim studijama je pokazano da odnos $\kappa / \lambda$ lakih lanaca predstavlja nezavisan faktor rizika za raniju progresiju u simptomatski MM. Imajući ovo $u$ vidu, abnormalni odnos $\operatorname{sFLC}(\kappa / \lambda) \geq 100$ uvršćen je u kriterijume za postojanje simptomatske bolesti i predstavlja indikaciju za započinjanje lečenja. Visoka koncentracija sFLC posledično dovodi do oštećenja bubrežne funkcije, te je redukcija sFLC za više od 50\% tokom inicijalnog lečenja jedan od glavnih faktora oporavka bubrežne funkcije i gubitka dijalizne zavisnosti. Prema kriterijumima Internacionalne Radne Grupe za multipli mijelom (International Myeloma Working Group, IMWG), sFLC se koristi i za procenu terapijskog odgovora kao kriterijum za tzv. potvrđenu kompletnu remisiju ("stringent complete remission", sCR). Dubina terapijskog odgovora nakon inicijalnog lečenja jedan je od najvažnijih prediktora dužine ukupnog preživljavanja ("overall survival", OS) (10).

\section{Ekstramedularna bolest}

Ekstramedularna bolest ("extramedullary disease", EMD) se karakteriše postojanjem plazmocitnih tumorskih formacija izvan primarnog ishodišta plazmocitnih neoplazija, odnosno kostne srži. Maligno izmenjeni plazmociti u EMD-u pokazuju nižu ekspresiju athezionih 
molekula i citokinskih receptora uz izraženiju angiogenezu (11). EMD u mijelomu se može manifestovati kao mekotkivni plazmocitom u sklopu MM, gde postoji zahvatanje mekih tkiva i pojedinih organa (najčešće jetra, koža, pleuralni prostor, bubrezi, limfni čvorovi, pankreas i nervni sistem), ili paraosealni plazmocitom u sklopu MM, kada tumorska masa izrasta iz fokalne koštane promene. Učestalost mekotkivnog plazmocitoma kreće se od 1,7\%-3,5\%, dok se paraosealna forma javlja u 6\%-34,4\% na prezentaciji bolesti. U relapsu incidencija EMD-a je viša, i može se javiti kod $10 \%$ bolesnika. Plazmocitnu leukemiju karakteriše prodor malignih ćelija u krv tj. prisustvo više od $2 \times 10^{9} / \mathrm{L}$ cirkulišućih plazmocita. Primarna plazmocitna leukemija je najređa forma bolesti koja se javlja kod 2-4\% MM pacijenata i karakteriše je najlošija prognoza, uz postizanje petogodišnjeg preživljavanja kod svega $10 \%$ bolesnika. EMD po svojim karakteristikama podseća na limfomska oboljenja i udružena je sa visokom koncentracijom $\mathrm{LDH}$, visokorizičnim citogenetskim abnormalnostima i plazmablastnom morfologijom. Imajući u vidu nezrelost malignih plazmocita u EMD-u, ovi tumori se najčešće odlikuju sekrecijom lakih lanaca imunoglobulina, oligo ili nesekretornim formama bolesti. EMD predstavlja visokorizičnu formu bolesti sa lošim odgovorom na inicijalnu hemioterapiju (HT), vrlo često udruženu sa primarnom refraktarnošću i ranim relapsima unutar godinu dana. Posledično, terapijski pristup u EMD-u zahteva intenzifikaciju lečenja, primenu trojnih ili četvorostrukih kombinacija lekova $\mathrm{u}$ indukcionoj terapiji, praćenoj visokodoznom hemioterapijom (VDHT) sa autologom transplantacijom matične ćelije hematopoeze (ATMĆH), a sve sa ciljem postizanja CR kao najvažnijeg prediktornog faktora trajanja vremena bez progresije bolesti (“progression-free survival", PFS) i OS (12-14).

Biomarkeri aktivnosti bolesti: Durie-Salmon klasifikacija i Internacionalni skoring sistem (ISS skor)

Prema IMWG kriterijumima iz 2014.godine definisana su tri osnovna biomarkera aktivnosti plazmocitne neoplazije: infiltracija srži monoklonskim Plc od minimum $60 \%$, sFLC odnos $\geq 100$, magnetnom rezonancom (NMR) utvrđena jedna ili više fokalnih lezija skeleta veličine najmanje $5 \mathrm{~mm}$, a prisustvo najmanje jednog od navedenih kriterijuma svrstava bolesnika u grupu sa simptomatskim MM koji zahteva lečenje.

U simptomatskom obliku bolesti, između pojedinih bolesnika postoji značajna razlika u OS koje se kreće u širokom rasponu od 2 pa do preko 10 godina $(15,16)$. Imajući ovo u vidu, adekvatna stratifikacija bolesnika u različite grupe rizika neophodna je za razvoj personalizovanog pristupa i strategije lečenja obolelih. Durie-Salmon klasifikacija, koja datira iz 1975. godine, definiše tri klinička stadijuma prema kliničkim parametrima (koncentracije M proteina, hemoglobina i serumskog kalcijuma, kao i promene na klasičnoj radiografiji skeleta), sa 2 podtipa u odnosu na postojanje bubrežne slabosti (17). Bolesnici sa bubrežnom slabošću na prezentaciji imaju značajno lošiju prognozu u odnosu na one sa normalnom bubrežnom funkcijom, nezavisno od oporavka iste nakon primene novih modaliteta terapije (18-20). Nedovoljna senzitivnost klasične radiografije u otkrivanju koštane bolesti i otkriće brojnih drugih parametara koji utiču na ishod i tok bolesti, doprineli su njenoj limitiranoj primeni. Durie-Salmon PLUS klasifikacija iz 2006. godine, inkorporira nalaze NMR pregleda i pozitronske kompjuterizovane tomografije (PET-CT) koji imaju značajno veću senzitivnost u otkrivanju koštanih lezija. (21).

Najveći pomak kad je u pitanju stratifikacija bolesnika sa MM ostvaren je formiranjem tzv. ISS skora. Zasnovan na koncentracijama albumina i beta-2-mikroglobulina, ISS skor predstavlja parametar aktivnosti bolesti, čime se definišu bolesnici niskog, umerenog i visokog rizika za dužinu OS-a (22-24).

\section{Karakteristike malignog klona}

Indeks udvajanja plazmocita (PCLI) predstavlja pokazatelj broja plazmocita koji se nalaze u deobi i parameter je proliferativne aktivnosti maligne bolesti. PCLI predstavlja nezavisan prognostički faktor bolesti i udružen je sa značajno kraćim trajanjem PFS-a i OS-a $(25,26)$. Takođe, kao nepovoljne karakteristike ističu se i plazmablastna morfologija i postojanje cirkulišućih plazmocita (27).

Molekularno genetske aberacije, prognostički značaj i revidirani ISS skor (R-ISS)

Napretkom molekularne genetike ostvaren je napredak u razumevanju biologije multiplog mijeloma, genskih promena i njihovom prognostičkom uticaju na tok i ishod lečenja. Višestepene genske alteracije tokom evolucije malignog klona mogu se podeliti na primarne i sekundarne. Primarne genske aberacije u multiplom mijelomu, odgovorne za klonsku proliferaciju, manifestuju se kao hiper- ili hipodiploidan kariotip i/ ili različite strukturne hromozomske aberacije poput delecija, amplifikacija i translokacija. Sekundarne aberacije se javljaju tokom bolesti i parameter su klonske evolucije $(24,28,29)$. Za detekciju ovih aberacija koristi se interfazna fluorescentna in situ hibridizacija (iFISH), obzirom da je proliferativni indeks ćelija nizak u mijelomu. Najčešće se sreće hiperdiploidni kariotip, koji je prisutan kod 50\% obolelih, parametar je bolesti standardnog rizika uz trajanje OS-a od 7-10 godina (30). Delecija 13q (del13q) je najčešća strukturna aberacija u MM-u, javlja se kod $>90 \%$ novodijagnostikovanih bolesnika. Prognostički je standardnog rizika ukoliko se detektuje iFISH metodom $(31,32)$. Najčeše translokacije su one koje obuhvataju gen za teški lanac imunoglobulina (IgH) koji se nalazi na 14 . hromozomu. Kod $40 \%$ bolesnika sreće se neka od od translokacija: $\mathrm{t}(4 ; 14) ; \mathrm{t}(14 ; 16) ; \mathrm{t}(14 ; 20)$; $\mathrm{t}(11 ; 14)$, čiji je prognostički uticaj različit. Postojanje $t(11 ; 14)$, sa učestalošću od oko $17 \%$, karakteriše standardni rizik i povoljan prognostički uticaj, dok uticaj pojedinih abnormalnosti, kao npr. $t(4 ; 14)$, prisutne kod $15 \%$ obolelih, zavisi od vrste primenjene terapije. Uvođenjem bortezomiba u lečenje obolelih od mijeloma prevaziđen je nepovoljan uticaj ove aberacije $\mathrm{i}$ ona se može 
okarakterisati kao abnormalnost standardnog rizika (3335). Druge translokacije, kao $\mathrm{t}(14 ; 16)$ koja zahvata MAF gen i prisutna je kod $5 \%$ bolesnika, ili t $(14 ; 20)$ koja obuhvata MAF-B gen kod 1-2\% obolelih, karakteriše agresivni tok bolesti sa nepovoljnim ishodom. Kada su u pitanju sekundarne genske aberacije, najčešće su delecije i amplifikacije pojedinih genskih lokusa. Delecija $17 \mathrm{p}$ (del17p) postoji kod 7-10\% bolesnika na prezentaciji, znatno je češća u relapsu bolesti i predstavlja visokorizičnu aberaciju (29). Bolesnike sa del17p u više od $60 \%$ ćelija karakteriše PFS od svega 14,6 meseci u odnosu na 34,7 meseci kod bolesnika sa manjim brojem ćelija sa del17p. Takođe, dokazan je uticaj ove abnormalnosti i na dužinu preživljavanja, koja je u korelaciji sa procentom ćelija koje karakteriše ova delecija $(36,37)$ (38). Od izuzetnog su značaja i abnormalnosti hromozoma 1 koje su češće u kasnijoj evoluciji bolesti. Najčešće se sreće amplifikacija regiona na dugom kraku, amplq kod 40$50 \%$ bolesnika, dok kratki krak hromozoma 1 karakterišu pre svega delecije, dellp kod 30\% bolesnika sa mijelomom. Obe abnormalnosti karakteriše visokorizična forma bolesti udružena sa kraćim OS $(31,39)$.
Visokorizične hromozomske aberacije (del $17 \mathrm{p}$, $\mathrm{t}(4 ; 14)$ i $\mathrm{t}(14 ; 16))$ objedinjene sa klasičnim ISS skorom i koncentracijom $\mathrm{LDH}$, čine parametre revidiranog ISS skora, tzv. R-ISS skor kojim su definisane tri prognostički različite grupe bolesnika (40). Prosečan PFS za bolesnike sa R-ISS skorom 1 je 66 meseci, 42 meseca za one sa R-ISS skorom 2, a 29 meseci za one sa R-ISS skorom 3. Petogodišnji OS za bolesnike sa R-ISS 1 je $82 \%$, za bolesnike sa R-ISS $262 \%$, dok je namanje petogodišnje preživljavanje od $40 \%$ karakterisalo grupu sa R-ISS3 skorom $(16,41)$ (tabela 1).

\section{Koncept „double” i „triple HIT” MM}

R-ISS skor ne integriše sve visokorizične citogenetske abnormalnosti koje se viđaju kod obolelih od MM, poput amp1q i dellp $(42,43)$. M-SMART 3.0 klasifikacija Mayo klinike integriše i ove aberacije, uz dodatno definisanje ultra-visokorizičnih bolesnika sa „double“ $i$ „triple hit" MM, odnosno one koje karakteriše udruženost 2 tj. $\geq 3$ visokorizičnih genskih abnormalnosti (tabela 2.). Kao visokorizične abnormalnosti izdvojene su

Tabela 1. R-ISS skor

\begin{tabular}{cc}
\hline R-ISS skor & ISS $1+$ citogenetske abnormalnosti standardnog rizika ${ }^{1}+$ normalna LDH \\
II & Ne ispunjava kriterijume za R-ISS 1 ili R-ISS 3 \\
III & ISS $3+$ citogenetske abnormalnosti visokog rizika ${ }^{2}$ i/ili povišena LDH \\
\hline $\begin{array}{l}{ }^{1} \text { Citogenetske abnormalnosti standardnog rizika su sve izuzev onih visokog rizika. }{ }^{2} \text { Citogenetske abnormalnosti visokog rizika su: } \\
\text { del17p i/ili t(4;14) i/ili t(14;16). Preuzeto i adaptirano - Palumbo et al. JCO } 2015 ;\end{array}$
\end{tabular}

Tabela 2. mSMART 3.0 Klasifikacija MM

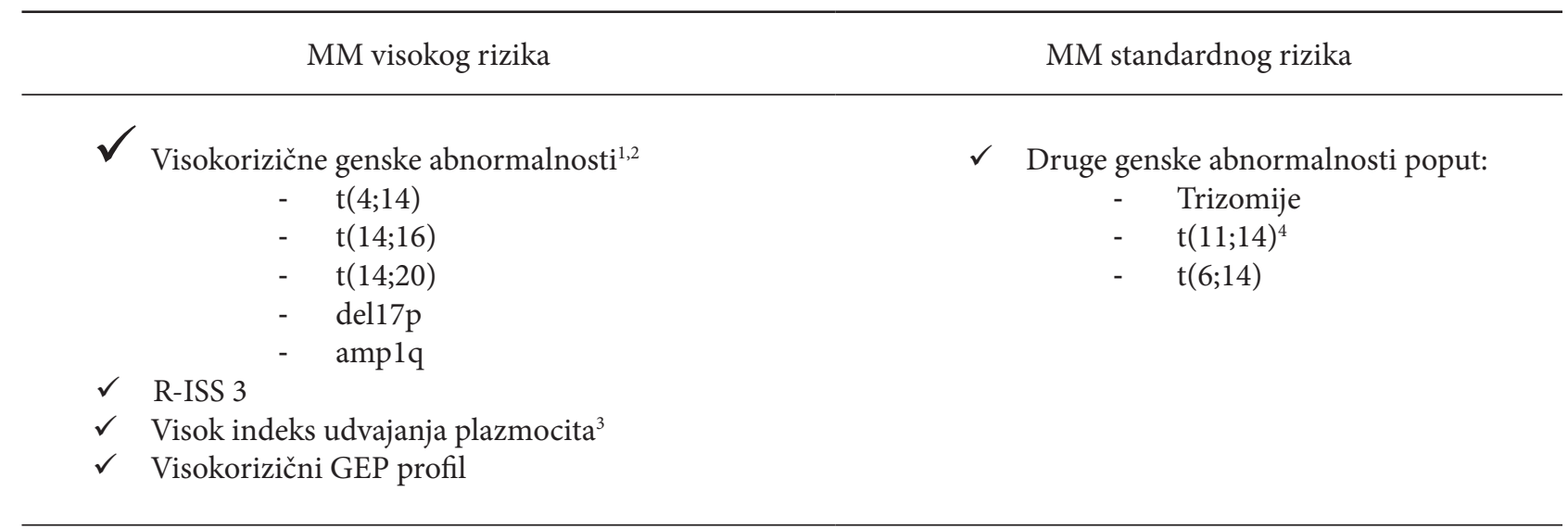

Double Hit MM: udruženost 2 visokorizične genske abnormalnosti

Triple Hit MM: udruženost 3 ili više visokorizičnih genskih abnormalnosti

\footnotetext{
${ }^{1}$ Udruženost sa trizomijama ublažava negativan prognostički značaj. ${ }^{2}$ Nalaz dobijen primenom iFISH-a ili ekvivalentnom metodom molekularne genetike. ${ }^{3}$ Različite "cut-off” vrednosti. ${ }^{4} \mathrm{t}(11 ; 14)$ može biti udružena sa nalazom plazmocitne leukemije. Preuzeto i adaptirano - Dispenzieri et al. Mayo Clin Proc. Poslednja revizija 2018.
} 
$\mathrm{t}(4 ; 14), \mathrm{t}(14 ; 16), \mathrm{t}(14 ; 20)$, del17p, mutacija p53 gena (TP53) gena i amp1q (44). Ono što se ne precizira ni u R-ISS skoru, a ni u M-SMART 3.0 klasifikaciji je alelski tip mutacije tumor supresor, p53 gena, u okviru delecije na kratkom kraku 17. hromozoma. Obzirom da se mutacija u jednom alelu p53 gena, koja se javlja $\geq 75 \%$ bolesnika sa del17p, ne karakteriše visokim rizikom, neophodno je identifikovati $25 \%$ bolesnika sa bialelskom mutacijom kao jedinim pravim visokorizičnim parametrom (45). U skladu sa tim, ,,double hit“ MM karakterišu bialelska mutacija TP53 gena, $\geq 4$ kopije CSK1B gena na hromozomu 1 i ISS skor 3 (46).

Analize profila genske ekspresije (GEP) i sledeća generacija sekvencioniranja (NGS)

Kako bi se istražio uticaj ekspresije pojedinih gena na tok bolesti, PFS i OS, razvijeno je nekoliko modela genskih platformi. Inicijalno je predstavljen GEP70 model koji je analizom 70 različitih genskih lokusa ukazao na razlike $\mathrm{u}$ PFS-u kod novodijagnostikovanih bolesnika u odnosu na njihov citogenetski profil, ISS skor, LDH i beta-2 mikroglobulin $(23,47)$. Još precizniji je model GEP15 koji se bazira na analizi 15 specifičnih genskih lokusa (48). Međutim, ove metode nisu zaživele u standardnoj kliničkoj praksi pre svega zbog vremenske i finansijske zahtevnosti metodologije. Takođe, od specifičnih hromozomskih abnormalnosti, del12p i amp5q pokazuju značajan uticaj na prognozu same bolesti (49). Analiza pojedinačnih genskih lokusa nije dovoljna da objasni heterogenost bolesti koja je rezultat svih promena u genomu. NGS predstavlja sofisticiranu metodu koja omogućava analizu velikog broja genskih lokusa i detekciju čitavog panela abnormalnosti malignih subklonova. $\mathrm{Na}$ taj način može se izvršiti sekvencioniranje čitavog genoma sa očekivanjem da će u budućnosti NGS zameniti iFISH metodu u potpunosti (50).

\section{Kliničke karakteristike bolesnika}

\section{Godine života i komorbiditetni status}

MM je bolest starije populacije što u velikoj meri otežava terapijski pristup, obzirom na brojne komorbiditete koji u velikoj meri utiču na izbor inicijalnog lečenja i ukupno preživljavanje. (51). U cilju optimizacije individualizovanog terapijskog pristupa teži se formiranju što sveobuhvatnijeg komorbiditetnog indeksa. Jedan od dobro poznatih skorova je Charlson-ov komorbiditetni indeks ("Charlson Comorbity Index", CCI) koji obuhvata 19 komorbiditetnih stanja. U skladu sa IMWG preporukama, opšte stanje i komorbiditeti predstavljaju faktore koji moraju zajedno biti analizirani i iskorišćeni prilikom izbora inicijalne terapije (52). Shodno tome, 2015. godine formiran je tzv. IMWG skor fragilnosti ("IMWG fraility score") koji je zasnovan na godinama starosti, Charlson-ovom komorbiditetnom indeksu, i indeksima osnovnih životnih ("Activities of daily living", ADL) i instrumentalnih aktivnosti ("Instrumental activities of daily living”, IADL), čime su definisane 3 grupe bolesnika različite podobnosti za aktivno hematološko lečenje (za lečenje: pogodni tzv. "fit", umereno pogodni tzv. "intermediate fit" i krhki tzv. "frail"). IMWG skor je nezavisan prediktivni faktor ranog smrtnog ishoda, nehematoloških komplikacija lečenja, terapijskog odgovora i progresivnog karaktera bolesti. U odnosu na IMWG skor, trogodišnje preživljavanje se postiže kod $84 \%$ za lečenje pogodnih bolesnika, $76 \%$ umereno pogodnih i 57\% krhkih bolesnika $(51,53)$. Indeks koji objedinjuje fizikalni nalaz kod bolesnika na prezentaciji bolesti ("performance status", PS) i komorbiditete je tzv. Freiburg komorbiditetni indeks, poznatiji kao Inicijalni komorbiditetni indeks obolelih od mijeloma (I-MCI), koji se bazira na Karnofski PS skoru, postojanju plućne ili bubrežne bolesti. On se pokazao prediktivnim u odnosu na preživljavanje nezavisno od stadijuma MM, godina starosti i izbora terapije (54). Objedinjavanjem parametara R-ISS skora, IMWG skora fragilnosti, klasičnog Kaplan-Feinistein indeksa (KFI) i komorbiditetnog indeksa podobnosti za transplantaciju matične ćelije hematopoeze ("Hematopoietic cell transplantation-specific comorbity index", HCT-SCI), 2017. godine formiran je Revidirani komorbiditetni indeks obolelih od mijeloma (R-MCI) (slika 1). Prema R-MCI skoru, bolesnici su podeljeni u tri grupe: niskog (0-3 poena), umerenog (4-6 poena), i visokog (7-9 poena) rizika. Osnovna prednost R-MCI skora je jednostavno izračunavanje i primenljivost u svakodnevnoj kliničkoj praksi.

\section{Karakteristike terapijskog odgovora}

Postizanje kompletne remisije i detekcija minimalne rezidualne bolesti (minimal residual disease, MRD)

Stepen i trajanje terapijskog odgovora značajno utiču na PFS i OS. Postizanje CR smatra se jednim od najsnažnijih prognostičkih markera $(56,57)$. Prema IMWG kriterijumima, postignuta CR se može gradirati kao: potvđena tzv. "stringent", sCR, imunofenotipski potvrđena i molekularna CR. Kriterijumi za CR su imunoelektroforezom nedetektabilan paraprotein uz manje od $5 \%$ plazmocita u srži, dok se sCR karakteriše odsustvom klonskih plazmocita dokazanog imunohistohemijskom ili imunofenotipskom analizom uz normalan odnos slobodnih lakih lanaca (sFLC). Imunofenotipska CR se definiše odsustvom klonskih plazmocita dokazanog pomoću $\geq 4$-kolorne protočne citometrije. Za molekularnu CR je neophodna negativnost tzv. Polymerase Chain Reaction (PCR) analize, na RNK neoplastičnih plazmocita (58). U cilju praćenja MRD-a kod bolesnika koji su postigli CR, a obzirom na loš prognostički značaj MRD pozitivnosti, IMWG je 2016. godine definisala kriterijume za utvrđivanje i praćenje MRD-a visokospecifičnim metodama molekularne biologije (NGS, multiparametarska protočna imunofenotipizacija tzv. MFC) i radiografske vizuelizacije metaboličke aktivnosti bolesti (PET-CT) (59). 


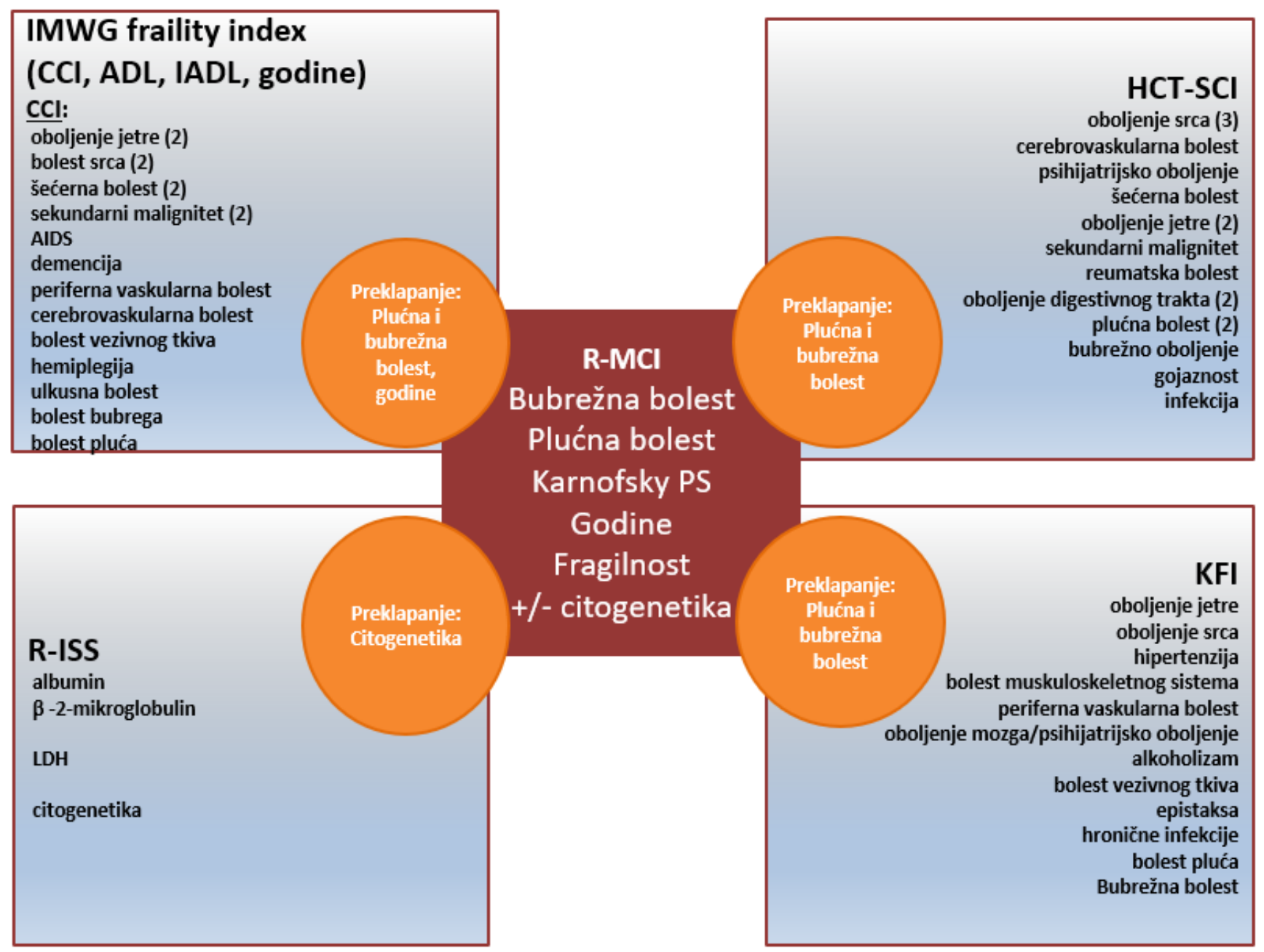

Slika 1. Revidirani komorbiditetni indeks obolelih od mijeloma (R-MCI). Preuzeto i adaptirano - M.Engelhardt et al. Haematologica 2017

\section{Zaključak}

Imajući u vidu navedene prognostičke faktore, objedinjene u okviru bioloških karakteristika bolesti, kliničke prezentacije bolesnika i karakteristika terapijskog odgovora, individualni prognostički profil zasniva se na:

1. Tipu i kliničkom stadijumu MM

2. Koncentraciji LDH i ISS skoru

3. Postojanju ekstramedularne lokalizacije bolesti

4. Prisustvu specifičnih hromozomskih aberacija i R-ISS skoru

5. Double ili triple hit vidu bolesti

6. GEP ili NGS profilu

7. IMWG i/ili HCT-SCI komorbiditetnom indeksu

8. Stepenu, dužini terapijskog odgovora i statusu MRD-a

Formiranje individualnog prognostičkog profila bolesnika sa multiplim mijelomom doprinosi adekvatnom individualizovanom terapijskom pristupu u cilju optimizacije terapijskog odgovora, maksimalnog produženja preživljavanja i postizanja izlečenja.

\section{Literatura}

1. Bila J, Mihaljević B. Multipli mijelom. U Marisavljević D, et ed. Klinička hematologija, Beograd, Zavod za udžbenike, 2012, 564-76;

2. Howlader N, Noone AM, Krapcho M, Miller D, Bishop K, Kosary CL, Yu M, Ruhl J, Tatalovich Z, Mariotto A, Lewis DR, Chen HS, Feuer EJ CK (eds). Myeloma - Cancer Stat Facts. SEER Cancer Statistics Review, 1975-2014. 2017.

3. Landgren O, Kristinsson SY, Goldin LR, Caporaso NE, Blimark C, Mellqvist UH, et al. Risk of plasma cell and lymphoproliferative disorders among 14621 first-degree relatives of 4458 patients with monoclonal gammopathy of undetermined significance in Sweden. Blood. 2009;

4. Landgren O, Weiss BM. Patterns of monoclonal gammopathy of undetermined significance and multiple myeloma in various ethnic/racial groups: Support for genetic factors in pathogenesis. Leukemia. 2009.

5. Kristinsson SY, Anderson WF, Landgren O. Improved longterm survival in multiple myeloma up to the age of 80 years. Leukemia. 2014.

6. Moreau P, Facon T, Leleu X, Morineau N, Huyghe P, Harousseau $\mathrm{JL}$, et al. Recurrent $14 \mathrm{q} 32$ translocations determine the prognosis of multiple myeloma, especially in patients receiving intensive chemotherapy. Blood. 2002;

7. Pandey S, Kyle RA. Unusual myelomas: A review of IgD and IgE variants. ONCOLOGY (United States). 2013. 
8. Zagouri F, Kastritis E, Symeonidis AS, Giannakoulas N, Katodritou E, Delimpasi S, et al. Immunoglobulin D myeloma: Clinical features and outcome in the era of novel agents. Eur J Haematol. 2014;

9. Rafae A, Malik MN, Abu Zar M, Durer S, Durer C. An Overview of Light Chain Multiple Myeloma: Clinical Characteristics and Rarities, Management Strategies, and Disease Monitoring. Cureus. 2018;

10. Bhole M V., Sadler R, Ramasamy K. Serum-free light-chain assay: Clinical utility and limitations. Ann Clin Biochem. 2014;51(5):528-42.

11. Bladé J, Fernández De Larrea C, Rosiñol L, Cibeira MT, Jiménez $\mathrm{R}$, Powles R. Soft-tissue plasmacytomas in multiple myeloma: Incidence, mechanisms of extramedullary spread, and treatment approach. Journal of Clinical Oncology. 2011.

12. Touzeau C, Moreau P. How i treat extramedullary myeloma. Blood. 2016;

13. Fernández De Larrea C, Kyle RA, Durie BGM, Ludwig H, Usmani $\mathrm{S}$, Vesole DH, et al. Plasma cell leukemia: Consensus statement on diagnostic requirements, response criteria and treatment recommendations by the International Myeloma Working Group. Leukemia. 2013.

14. Beksac M, Seval GC, Kanellias N, Coriu D, Rosiñol L, Ozet G, et al. A real world multicenter retrospective study on extramedullary disease from Balkan Myeloma Study Group and Barcelona University: Analysis of parameters that improve outcome. Haematologica. 2020;

15. Boyd KD, Ross FM, Chiecchio L, Dagrada GP, Konn ZJ, Tapper WJ, et al. A novel prognostic model in myeloma based on co-segregating adverse FISH lesions and the ISS: Analysis of patients treated in the MRC Myeloma IX trial. Leukemia. 2012;

16. Palumbo A, Avet-Loiseau H, Oliva S, Lokhorst HM, Goldschmidt $\mathrm{H}$, Rosinol L, et al. Revised international staging system for multiple myeloma: A report from international myeloma working group. J Clin Oncol. 2015;

17. Durie BGM, Salmon SE. A clinical staging system for multiple myeloma correlation of measured myeloma cell mass with presenting clinical features, response to treatment, and survival. Cancer. 1975 ;

18. Ludwig H, Hajek R, Tothova E, Drach J, Zdenek A, Labar B, et al. Thalidomide-dexamethasone compared with melphalan-prednisolone in elderly patients with multiple myeloma. Blood. 2009;

19. Ríos-Tamayo R, Sáinz J, Martínez-López J, Puerta JM, Chang DYL, Rodríguez T, et al. Early mortality in multiple myeloma: the time-dependent impact of comorbidity: A population-based study in 621 real-life patients. Am J Hematol. 2016;

20. Dimopoulos MA, Delimpasi S, Katodritou E, Vassou A, Kyrtsonis MC, Repousis P, et al. Significant improvement in the survival of patients with multiple myeloma presenting with severe renal im pairment after the introduction of novel agents. Ann Oncol. 2014;

21. Filonzi G, Mancuso K, Zamagni E, Nanni C, Spinnato P, Cavo M, et al. A comparison of different staging systems for multiple myeloma: Can the mri pattern play a prognostic role? In: American Journal of Roentgenology. 2017.

22. Greipp PR, Miguel JS, Dune BGM, Crowley JJ, Barlogie B, Bladé $\mathrm{J}$, et al. International staging system for multiple myeloma. J Clin Oncol. 2005;

23. Ziogas DC, Dimopoulos MA, Kastritis E. Prognostic factors for multiple myeloma in the era of novel therapies. Expert Review of Hematology. 2018.

24. Solimando AG, Da Vià MC, Cicco S, Leone P, Di Lernia G, Giannico D, et al. High-Risk Multiple Myeloma: Integrated Clinical and Omics Approach Dissects the Neoplastic Clone and the Tumor Microenvironment. J Clin Med. 2019;

25. Greipp PR, Kumar S. Plasma cell labeling index. Methods Mol Med. 2005;

26. Aljama MA, Hasib Sidiqi M, Lakshman A, Dispenzieri A Jevremovic D, Gertz MA, et al. Plasma cell proliferative index is an independent predictor of progression in smoldering multiple myeloma. Blood Adv. 2018;

27. Ribourtout B, Zandecki M. Plasma cell morphology in multiple myeloma and related disorders. Morphologie. 2015.
28. Kuehl WM, Bergsagel PL. Multiple myeloma: Evolving genetic events and host interactions. Nature Reviews Cancer. 2002.

29. Manier S, Salem KZ, Park J, Landau DA, Getz G, Ghobrial IM. Genomic complexity of multiple myeloma and its clinical implications. Nature Reviews Clinical Oncology. 2017.

30. Chretien ML, Corre J, Lauwers-Cances V, Magrangeas F, Cleynen A, Yon E, et al. Understanding the role of hyperdiploidy in myeloma prognosis: Which trisomies really matter? Blood. 2015;

31. Chng WJ, Glebov O. Genetic events in the pathogenesis of multiple myeloma. 2007;20(4):571-96.

32. Fassas ABT, Spencer T, Sawyer J, Zangari M, Lee CK, Anaissie $\mathrm{E}$, et al. Both hypodiploidy and deletion of chromosome 13 independently confer poor prognosis in multiple myeloma. Br J Haematol. 2002;118(4):1041-7.

33. Cavo M, Tacchetti P, Patriarca F, Petrucci MT, Pantani L, Galli $\mathrm{M}$, et al. Bortezomib with thalidomide plus dexamethasone compared with thalidomide plus dexamethasone as induction therapy before, and consolidation therapy after, double autologous stem-cell transplantation in newly diagnosed multiple myeloma: A randomised phase 3. Lancet. 2010;

34. Sonneveld P, Goldschmidt H, Rosiñol L, Bladé J, Lahuerta JJ, Cavo M, et al. Bortezomib-based versus nonbortezomib-based induction treatment before autologous stem-cell transplantation in patients with previously untreated multiple myeloma: A meta-analysis of phase III randomized, controlled trials. J Clin Oncol. 2013;

35. Sonneveld P, Schmidt-Wolf IGH, Van Der Holt B, El Jarari L, Bertsch U, Salwender $\mathrm{H}$, et al. Bortezomib induction and maintenance treatment in patients with newly diagnosed multiple myeloma: Results of the randomized phase III HOVON-65/ GMMG-HD4 trial. J Clin Oncol. 2012;

36. Usmani SZ, Rodriguez-Otero P, Bhutani M, Mateos M V., Miguel JS. Defining and treating high-risk multiple myeloma. Leukemia. 2015.

37. Neben K, Jauch A, Bertsch U, Heiss C, Hielscher T, Seckinger A, et al. Combining information regarding chromosomal aberrations $\mathrm{t}(4 ; 14)$ and $\operatorname{del}(17 \mathrm{pl} 3)$ with the international staging system classification allows stratification of myeloma patients undergoing autologous stem cell transplantation. Haematologica. 2010;

38. Merz M, Hielscher T, Seckinger A, Hose D, Mai EK, Raab MS et al. Baseline characteristics, chromosomal alterations, and treatment affecting prognosis of deletion $17 \mathrm{p}$ in newly diagnosed myeloma. Am J Hematol. 2016;

39. Ry SUMMA. Prognostic value of $1 p$ deletion for multiple myeloma : a. 2014;555-65.

40. Chim CS, Sim J, Tam S, Tse E, Lie AKW, Kwong YL. LDH is an adverse prognostic factor independent of ISS in transplant-eligible myeloma patients receiving bortezomib-based induction regimens. Eur J Haematol. 2015;

41. Bila J, Jelicic J, Dencic Fekete M, Trajkovic G, Sretenovic A, Perunicic Jovanovic $\mathrm{M}$, et al. The revised international staging system compared to the classical international staging system better discriminates risk groups among transplant-ineligible multiple myeloma patients. Oncol Res Treat. 2017;

42. Marzin Y, Jamet D, Douet-Guilbert N, Morel F, Le Bris MJ, Morice $\mathrm{P}$, et al. Chromosome 1 abnormalities in multiple myeloma. Anticancer Res. 2006;26(2 A):953-9.

43. Caltagirone S, Ruggeri M, Aschero S, Gilestro M, Oddolo D, Gay F, et al. Chromosome 1 abnormalities in elderly patients with newly diagnosed multiple myeloma treated with novel therapies. Haematologica. 2014;

44. Baysal M, Demirci U, Umit E, Kirkizlar HO, Atli EI, Gurkan H, et al. Concepts of Double Hit and Triple Hit Disease in Multiple Myeloma, Entity and Prognostic Significance. Sci Rep. 2020;

45. Jovanović KK, Escure G, Demonchy J, Willaume A, Van De Wyngaert Z, Farhat M, et al. Deregulation and targeting of TP53 pathway in multiple myeloma. Frontiers in Oncology. 2019. 
46. Walker BA, Mavrommatis K, Wardell CP, Ashby TC, Bauer M, Davies F, et al. A high-risk, Double-Hit, group of newly diagnosed myeloma identified by genomic analysis. Leukemia. 2019;

47. Broyl A, Hose D, Lokhorst H, De Knegt Y, Peeters J, Jauch A, et al. Gene expression profiling for molecular classification of multiple myeloma in newly diagnosed patients. Blood. 2010;

48. Decaux O, Lodé L, Magrangeas F, Charbonnel C, Gouraud W, Jézéquel $\mathrm{P}$, et al. Prediction of survival in multiple myeloma based on gene expression profiles reveals cell cycle and chromosomal instability signatures in high-risk patients and hyperdiploid signatures in low-risk patients: A study of the Intergroupe Francophone du Myélom. J Clin Oncol. 2008;

49. Avet-Loiseau H, Li C, Magrangeas F, Gouraud W, Charbonnel C, Harousseau JL, et al. Prognostic significance of copy-number alterations in multiple myeloma. J Clin Oncol. 2009;

50. Bolli N, Genuardi E, Ziccheddu B, Martello M, Oliva S, Terragna C. Next-Generation Sequencing for Clinical Management of Multiple Myeloma : Ready for Prime Time ? 2020;10(February).

51. Palumbo A, Bringhen S, Mateos MV, Larocca A, Facon T, Kumar SK, et al. Geriatric assessment predicts survival and toxicities in elderly myeloma patients: An International Myeloma Working Group report. Blood. 2015;

52. Palumbo A, Bringhen S, Ludwig H, Dimopoulos MA, Bladé J, Mateos M V., et al. Personalized therapy in multiple myeloma according to patient age and vulnerability: A report of the European Myeloma Network (EMN). Blood. 2011.

53. Mina $\mathrm{R}$, Bringhen $\mathrm{S}$, Wildes TM, Zweegman S, Rosko AE. Approach to the Older Adult With Multiple Myeloma. Am Soc Clin Oncol Educ B. 2019;(39):500-18.
54. Kleber M, Ihorst G, Groß B, Koch B, Reinhardt H, Wäsch R, et al. Validation of the Freiburg Comorbidity Index in 466 Multiple Myeloma Patients and Combination With the International Staging System Are Highly Predictive for Outcome. Clin Lymphoma, Myeloma Leuk [Internet]. 2013;13(5):541-51. Available from: http://dx.doi.org/10.1016/j.clml.2013.03.013

55. Engelhardt M, Domm AS, Dold SM, Ihorst G, Reinhardt H, Zober A, et al. A concise revised myeloma comorbidity index as a valid prognostic instrument in a large cohort of 801 multiple myeloma patients. Haematologica. 2017;

56. Fulciniti M, Munshi NC, Martinez-Lopez J. Deep Response in Multiple Myeloma: A Critical Review. Biomed Res Int 2015;2015(Table 2).

57. Lonial S, Anderson KC. Association of response endpoints with survival outcomes in multiple myeloma. Leukemia [Internet]. 2014;28(2):258-68. Available from: http://dx.doi.org/10.1038/ leu.2013.220

58. Rajkumar SV, Harousseau JL, Durie B, Anderson KC, Dimopoulos M, Kyle R, et al. Consensus recommendations for the uniform reporting of clinical trials: Report of the

59. Kumar S, Paiva B, Anderson KC, Durie B, Landgren O, Moreau $\mathrm{P}$, et al. International Myeloma Working Group consensus criteria for response and minimal residual disease assessment in multiple myeloma. The Lancet Oncology. 2016. 